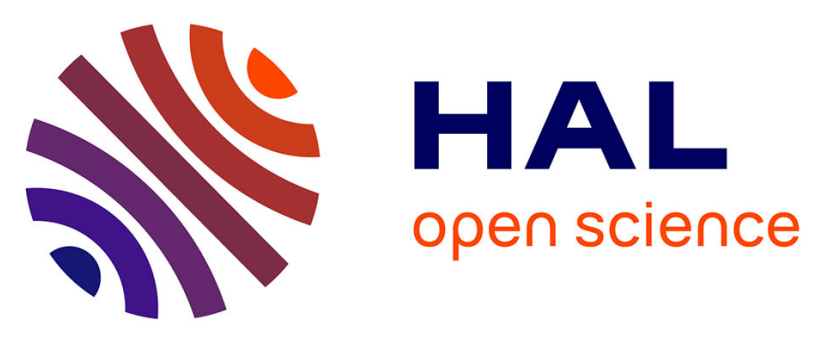

\title{
Characterisation of an \\ exo-( $\alpha-1,3)-3,6$-anhydro-D-galactosidase produced by the marine bacterium Zobellia galactanivorans DsijT: Insight into enzyme preference for natural carrageenan oligosaccharides and kinetic characterisation on a novel chromogenic substrate
}

\author{
Michael Wallace, Laura Guée, David Ropartz, Mathieu Fanuel, Guillaume \\ Lannuzel, Gaëlle Correc, Keith Stubbs, Elizabeth Ficko-Blean
}

\section{To cite this version:}

Michael Wallace, Laura Guée, David Ropartz, Mathieu Fanuel, Guillaume Lannuzel, et al.. Characterisation of an exo-( $\alpha-1,3)-3,6$-anhydro-D-galactosidase produced by the marine bacterium Zobellia galactanivorans DsijT: Insight into enzyme preference for natural carrageenan oligosaccharides and kinetic characterisation on a novel chromogenic substrate. International Journal of Biological Macromolecules, 2020, 163, pp.1471-1479. 10.1016/j.ijbiomac.2020.07.298 . hal-02950548

\author{
HAL Id: hal-02950548 \\ https://hal.science/hal-02950548
}

Submitted on 26 Nov 2020

HAL is a multi-disciplinary open access archive for the deposit and dissemination of scientific research documents, whether they are published or not. The documents may come from teaching and research institutions in France or abroad, or from public or private research centers.
L'archive ouverte pluridisciplinaire HAL, est destinée au dépôt et à la diffusion de documents scientifiques de niveau recherche, publiés ou non, émanant des établissements d'enseignement et de recherche français ou étrangers, des laboratoires publics ou privés. 
Characterisation of an exo-( $\alpha-1,3)-3,6$-anhydro-D-galactosidase produced by the marine bacterium Zobellia galactanivorans $\mathrm{Dsij}^{\mathrm{T}}$; insight into enzyme preference for natural carrageenan oligosaccharides and kinetic characterisation on a novel chromogenic substrate

Michael D. Wallace ${ }^{1}$, Laura Guée ${ }^{2}$, David Ropartz ${ }^{3,4}$, Mathieu Fanuel ${ }^{3,4}$, Guillaume Lannuzel², Gaëlle Correc $^{2}$, Keith A. Stubbs ${ }^{1 *}$ and Elizabeth Ficko-Blean ${ }^{2 *}$

${ }^{1}$ School of Molecular Sciences, The University of Western Australia, Crawley, WA 6009, Australia.

${ }^{2}$ CNRS, Sorbonne Université, UMR 8227, Integrative Biology of Marine Models, Station Biologique de Roscoff, CS 90074 Roscoff, Bretagne, France

${ }^{3}$ INRAE, UR BIA, F-44316 Nantes, France

${ }^{4}$ INRAE, BIBS facility, F-44316 Nantes, France

*corresponding authors: Keith A. Stubbs (E-mail keith.stubbs@uwa.edu.au) and Elizabeth Ficko-Blean (E-mail efickoblean@sb-roscoff.fr)

Running Title: exo-( $\alpha-1,3)-3,6$-anhydro-D-galactosidase GH129 biochemistry

Keywords: GH129, red algae, cell wall, carrageenan, polysaccharide utilization locus, 4-nitrophenyl 3,6anhydro- $\alpha$-D-galactoside, 


\begin{abstract}
Flavobacteriia are important degraders in the marine carbon cycle, due to their ability to efficiently degrade complex algal polysaccharides. A novel exo-( $\alpha-1,3)-3,6$-anhydro-D-galactosidase activity was recently discovered from a marine Flavobacteriia (Zobellia galactanivorans Dsij ${ }^{\mathrm{T}}$ ) on red algal carrageenan oligosaccharides. The enzyme activity is encoded by a gene found in the first described carrageenan-specific polysaccharide utilisation locus (CarPUL) that codes for a family 129 glycoside hydrolase (GH129). The GH129 family is a CAZy family that is strictly partitioned into two niche-based clades: clade 1 contains human host bacterial enzymes and clade 2 contains marine bacterial enzymes. Clade 2 includes the GH129 exo-( $\alpha-1,3)-3,6$-anhydro-D-galactosidase from Z. galactanivorans ( $\mathrm{ZgGH} 129)$. Despite the discovery of the unique activity for $Z g \mathrm{GH} 129$, finer details on the natural substrate specificity for this enzyme are lacking. Examination of enzyme activity on natural carrageenan oligomers using mass spectrometry demonstrated that $Z g G H 129$ hydrolyses terminal 3,6-anhydro-Dgalactose from unsulfated non-reducing end neo- $\beta$-carrabiose motifs. Due to the lack of chromogenic substrates to examine exo-( $\alpha-1,3)-3,6$-anhydro-D-galactosidase activity, a novel substrate was synthesised to facilitate the first kinetic characterisation of an exo-( $\alpha-1,3)-3,6$-anhydro-D-galactosidase, allowing determination of $\mathrm{pH}$ and temperature optimums and Michaelis-Menten steady state kinetic data.
\end{abstract}

\title{
1. Introduction
}

Macroalgae (seaweed) are main primary producers of coastal ecosystems and support a large coastal food web [1]. Unlike land plants, the extracellular matrices of macroalgae are dominated by the presence of sulfated polysaccharides [2]. These highly complex biopolymers can also vary in structure through alternating linkages, additional modifications (e.g. glycosylation, pyruvation and methylation) and sulfation isoforms [2]. Due to their diverse chemical structures, these sulfated algal polysaccharides are 
exploited in the alimentary and cosmetic industry for their rheological properties [3]. Furthermore, sulfated polysaccharides and the oligosaccharides derived from them often demonstrate bioactivities in vitro, such as immunostimulatory and anti-viral activities [4]. This is presumably due to their resemblance to metazoan sulfated sugars such as those found in the heavily glycosylated mucosal material lining the entryways to the body and the connective tissue glycoaminoglycans. Thus, the ability to tailor the physiochemical properties of these algal carbohydrates enzymatically is of strong biotechnological interest.

Coastal organic matter produced by marine macrophytes is largely recycled by marine heterotrophic bacteria. These bacteria have developed exquisite machinery to process the highly complex seaweed polysaccharides found within this material. For example, diverse bacterial species have grouped together genes encoding proteins involved in the processing of defined polysaccharides into genetic loci called polysaccharide utilisation loci (PULs) [5-11]. PULs were first classified in Bacteroides [12, 13]; however, recently the definition has been expanded to other bacterial phyla [6]. Within a 'typical' PUL the genes encode highly specialised proteins involved in recognition, catalysis, transport and regulation of PUL function. PULs are a rich enzymatic resource, unlocking an unknown PUL specificity for a defined polysaccharide can result in the discovery of novel CAZyme families and/or novel activities within already created CAZyme families (http://www.cazy.org/) [14]. Recently several marine bacterial PULs have been described [15-17], including PULs specific for the complex red algal extracellular matrix polysaccharide carrageenan $[6,8,18,19]$.

Carrageenan is a complex sulfated galactan with alternating $\alpha-1,3-$ and $\beta-1,4$-linkages. $\beta-, \kappa_{-}$and $\iota^{-}$ carrageenan differ in their degree of sulfation (none, one and two sulfates, respectively) but all have the repeating disaccharide unit -[3,6-anhydro-D-galactose-( $\alpha-1,3)$-D-galactose-( $\beta-1,4)]$ - (Figure 1A). The monosaccharide 3,6-anhydro-D-galactose is a bicyclic sugar, unique to red algae; the 3,6-anhydro-bridge 
is formed through the action of sulfurylases [20] a group of enzymes with biochemistry also unique to red algae which utilise the D-galactose-6-sulfate variant as a substrate for ring closure. Within the carrageenan chain the $\beta$-1,4-linked D-galactose is maintained in a ${ }^{4} \mathrm{C}_{1}$ conformation [2]. However, the 3,6-anhydrobridge introduces strict structural constraints on the $\alpha$-1,3-linked 3,6-anhydro-D-galactose monosaccharide resulting in a ring inversion to the ${ }^{1} \mathrm{C}_{4}$ conformation and consequentially its $\alpha$-linkage and C4 hydroxyl group are maintained equatorially within the carrageenan chain [2] (Figure 1A).

Marine bacterial glycoside hydrolase activities hydrolysing the $\beta-1,4$ linkage in carrageenan have been well described in the literature [21-24]; however, only recently has an enzyme activity been described as active on the $\alpha-1,3$ linkage [6]. Recent experiments revealed a novel exo-3,6-anhydro-D-galactosidase activity [6] in a family 129 glycoside hydrolase (GH129) member coded by the gene zgal_3152 in Zobellia galactanivorans $\mathrm{Dsij}^{\mathrm{T}}$, a marine model Flavobacteriaceae (bacterial phylum Bacteroidetes) isolated from a healthy red alga [25, 26]. The enzyme, termed $Z g G H 129$, cleaves 3,6-anhydro-D-galactose residues from the non-reducing end of neo-carrageenan oligosaccharides to produce novel oligosaccharides with D-galactose on the non-reducing terminus [6]. The elucidation of the function of zgal_3152 led to the discovery of a polysaccharide utilization locus (PUL) and complex regulon responsible for carrageenan degradation in Z. galactanivorans [6]. Further experiments also identified 3,6-anhydro-D-galactosidase activity in three family 127 glycoside hydrolase (GH127) members located within the same carrageenan PUL (CarPUL) [6]. In marine Pseudoalteromonas species the GH127 and GH129 family members are absent $[8,18]$ though certain Pseudoalteromonas species with CarPULs display growth on $\kappa$ - and 1 -carrageenan suggesting that the source of the ( $\alpha-1,3)-3,6$-anhydro-Dgalactosidase activity in these species remains to be discovered [8].

The GH129 family was first identified based on distant sequence similarity to family 101 glycoside hydrolases [27]. The first characterised GH129 enzyme, BbGH129, termed NagBb, is an exo- $\alpha-N-$ 
acetylgalactosaminidase produced by the human gut bacterium Bifidobacterium bifidum JCM 1254 and is implicated in mucin degradation [27]. Catalytically, BbGH129 proceeds using a retaining mechanism [27] and the catalytic nucleophile (BbAsp435) and acid/base residue (BbGlu478) have been identified through crystallographic analyses [pdb id 5wzn [28], Figure 1B]. Consistent with this data, ZgGH129 [pdb id 5opq [6]] shares the crystallographically predicted nucleophile and acid/base catalytic residues with BbGH129 (Figure 1B).

Despite the discovery of the unique exo-( $\alpha-1,3)-3,6$-anhydro-D-galactosidase activity for $Z g \mathrm{GH} 129$ [6], detailed information on the subsite preferences is lacking and thus more experiments to examine the specificity of this enzyme on natural substrate are needed. Here we investigate the unusual exo-( $\alpha-1,3)$ 3,6-anhydro-D-galactosidase enzyme activity of $Z g G H 129$ on its natural carrageenan substrate and on a novel artificial chromogenic substrate, thus allowing for determination of the fine substrate specificity, pH optimum, temperature optimum and steady state Michalis-Menten kinetics data.

\section{Results and Discussion}

\subsection{Phylogeny of the GH129 enzymes}

A phylogenetic tree using 100 enzyme sequences from different bacterial species was constructed for the GH129 family of enzymes using a maximum likelihood approach and the Whelan and Goldman model [29]. Three characterised GH101 enzymes were used as an outgroup based on their distant sequence similarity to the GH129 family [30-32]. The tree with the highest log likelihood (-16026.33) is shown (Figure 1C) and the percentage of trees in which the associated taxa clustered together is shown next to the branches. The GH129 family consists only of bacterial members and the family divides into two distinct clades (Figure 1C and Supplementary File 1) with excellent bootstrap values of 99. Clade 1 
contains bacterial members that have animal, including human, hosts and/or members that were sourced from human feces. Clade 2 contains bacteria from the marine niche and includes one member that has an animal host: Flavobacterium faecale, isolated from the stools of Antarctic penguins [33]. The clade 1 bacterial members are more diverse than their clade 2 counterparts and contain members from three Gram-positive Firmicutes from the Class Clostridia, several Gram-positive Bifidobacterium species and one Gram-negative Victivallales isolated from sewage sludge [34]. All of the marine clade 2 bacterial members are found in the Gram-negative Bacteroidetes phyla, either in Class Flavobacteriia or Cytophagia. The strict phylogenetic divide along niches within the GH129 family suggests another evolutionary example of a horizontal gene transfer event from a marine bacterium to a gut bacterium [6, 35]. Within clade 1 (Figure 1C) is the first characterised GH129 enzyme from the gut bacterium Bifidobacterium bifidum (NagBb), which is an exo- $\alpha-N$-acetylgalactosaminidase active on mucosal glycans [27]. Clade 2 accommodates the novel exo-( $\alpha-1,3)-3,6$-anhydro-D-galactosidase activity discovered on carrageenan oligosaccharides that is encoded in a PUL in the marine bacterium $Z$. galactanivorans [6].

The strong divide of the GH129 clades along the bacterial niches likely represents the different biochemistries of the GH129 enzymes between these niches. The conformations of the non-reducing end D-galactose substrate moieties differ significantly $-{ }^{4} \mathrm{C}_{1}$ for $N$-acetyl-D-galactosamine (GalNAc, clade 1) and ${ }^{1} \mathrm{C}_{4}$ for 3,6-anhydro-D-galactose (clade 2), as the 3,6-anhydro-bridge found in the latter monosaccharide inflicts strict conformational constraints on the structure. The ring flip from ${ }^{4} \mathrm{C}_{1}$ to ${ }^{1} \mathrm{C}_{4}$ also results in the hydroxyl group at $\mathrm{C} 4$ and the anomeric carbon flipping from axial to equatorial positions. Furthermore, the sugar decorations change the chemical nature of the monosaccharides, an $\mathrm{N}$-acetyl group at C2 of GalNAc (clade 1) introduces a polar group whereas the 3,6-anhydro-bridge (clade 2) introduces a hydrophobic surface to the C6 face of the monosaccharide. These major differences between sugar structures is supported by the divergent enzyme activities and different bacterial niches described for the two clades. 
The structure of the clade $1 B b \mathrm{GH} 129$ [pdb id 5wzn [28]] was determined in complex with GalNAc in the -1 subsite, allowing crystallographic prediction of the nucleophile (BbAsp435) and acid/base (BbGlu478) catalytic residues (Figure 1B). The predicted catalytic residues are shared within the GH129 family. The structure of the clade $2 \mathrm{ZgGH} 129$ [pdb id 5opq [6]] has only been determined in complex with a bound Tris molecule in the predicted -1 site to date. Other than the critical catalytic residues, the active site architectures of the two characterised GH129 enzymes are quite different (Figure 1B). One major difference is the coordination of a divalent cation within the active site of BbGH129 which is absent in $\mathrm{ZgGH} 129$. There is also a perpendicular shift of the hydrophobic tryptophan platform between the two active sites. Another key difference is the participation of both monomers in the $Z g \mathrm{GH} 129$ active site which does not occur in BbGH129 as ZgGH129 exists as a homodimer and BbGH129 is monomeric. Overall, these variances in -1 active site sub-structure likely play an important role in defining the differences in substrate recognition between the two GH129 enzymes.

\subsection{Deeper insight into ZgGH129 substrate specificity}

Initial biochemical analyses of $Z g G H 129$ indicated $Z g G H 129$ could hydrolyse the 3,6-anhydro-Dgalactose moiety carrageenan oligosaccharides [6]. One question that remained unclear from the study was whether $\mathrm{ZgGH} 129$ is capable of hydrolysing the 3,6-anhydro-D-galactose moiety from a nonreducing neo- $\beta$-carrabiose motif or a neo- $\kappa$-carrabiose motif. To investigate, and described in detail below, mass spectrometry methods were used to characterise the $Z g G H 129$ activity on a natural carrageenan oligosaccharide substrate initially predicted to be neo- $\kappa-D P 6$ based on mass.

Furcellaran, from the extracellular matrix of the red alga Furcellaria lumbricalis, is composed primarily of $\beta$ - and $\kappa$-carrageenan motifs [36]. To obtain carrageenan oligosaccharide substrates for $Z g \mathrm{GH} 129$ with the 3,6-anhydro-D-galactose moiety on the non-reducing terminus (the neo-series of oligosaccharides), 
furcellaran was treated with the $\kappa$-carrageenase from Pseudoalteromonas carrageenovora. As described, this endolytic enzyme hydrolyses the $\beta$-1,4-linkage between the D-galactose-4-sulfate and 3,6-anhydro-Dgalactose motifs [23]. From this knowledge, all oligosaccharides released enzymatically using this methodology have 3,6-anhydro-D-galactose on the non-reducing end and D-galactose-4-sulfate on the reducing end [36].

The reactions obtained from the $\kappa$-carrageenase from Pseudoalteromonas carrageenovora, with and without a consecutive action of $Z g G H 129$ were analysed using MALDI mass spectrometry (Figure 2). Before the action of the $\mathrm{ZgGH} 129$ enzyme (Figure 2A), signals attributed to five oligo-carrageenans with a degree of polymerisation (DP) from 6 to 8 were found in the mass range $m / z 800-1500$. Species at $m / z$ 1423.295 and $\mathrm{m} / \mathrm{z} 1117.192$ respectively correspond to a DP8 containing $2 . \kappa+2 . \beta$ motifs $(\kappa-\beta-\beta-\kappa$ or $\beta-\kappa-$ $\beta-\kappa$ or $\beta-\beta-\kappa-\kappa)$ and a DP6 containing $2 . \kappa+1 \beta$ motifs (either $\kappa-\beta-\kappa$ or $\beta-\kappa-\kappa)$ as $[\mathrm{M}-2 \mathrm{H}+\mathrm{Na}]^{-}$ions for both species. The species at $\mathrm{m} / \mathrm{z} 1321.352$ and $\mathrm{m} / \mathrm{z} 1015.241$ were attributed to sulfate losses during the experiment as $[\mathrm{M}-\mathrm{H}]^{-}$ions (Figure $2 \mathrm{~A}$ ). Sulfate losses (corresponding to a $\mathrm{SO}_{3} \mathrm{Na}$ loss) are commonly observed upon MALDI ionisation even when using 2,5-dihydroxybenzoic acid/ $N, N$-dimethylaniline (DMA-DHB) as a matrix, which strongly reduces the loss of labile functionalities [37]. After the action of the $\mathrm{ZgGH} 129$ enzyme (Figure 2B) additional species were observed. Species observed at $\mathrm{m} / \mathrm{z} 1279.248$ and $\mathrm{m} / \mathrm{z} 973.150$ were attributed to hydrolysis of the non-reducing $\alpha$-1,3-linked 3,6-anhydro-D-galactose as $[\mathrm{M}-2 \mathrm{H}+\mathrm{Na}]^{-}$ions. The species attributed to sulfate losses of these products were also detected at $\mathrm{m} / \mathrm{z}$ 1177.308 and $\mathrm{m} / \mathrm{z} 871.199$ respectively as $[\mathrm{M}-\mathrm{H}]^{-}$ions (Figure 2B). These results correlate with the expected exo-3,6-anhydro-D-galactosidase activity of $Z g G H 129$. Conversely, the activity of $Z g G H 129$ on the unknown DP6 species released by the use of the $\kappa$-carrageenase required additional experiments (Figure 2). In accordance with the 'ideal' composition of the carrageenan furcellaran, the species at $\mathrm{m} / \mathrm{z}$ 1219.118 (Figure 2A) could be attributed to a neo- $\kappa-D P 6$ oligosaccharide $(\kappa-\kappa-\kappa)$ as a $[\mathrm{M}-3 \mathrm{H}+2 \mathrm{Na}]^{-}$ion. After incubation of this DP6 with $\mathrm{ZgGH129}$ an ion at $\mathrm{m} / \mathrm{z} 1075.087$ appeared (Figure 2B) with the 
corresponding loss of the peak at $\mathrm{m} / \mathrm{z}$ 1219.118. This unexpected result could correspond to the loss of a 3,6-anhydro-D-galactose residue on a pure neo-k-DP6; however, $Z g$ GH129 has not demonstrated activity when tested previously on pure neo- $\kappa$-carrageenan oligosaccharide standards [6].

The structures of the unknown DP6 and the corresponding product species were further examined using ESI-MSMS. Species were isolated at $m / z, 598.1$ as an $[\mathrm{M}+\mathrm{Na}-3 \mathrm{H}]^{2-}$ ion for the DP6 and $m / z, 526.0$ as an $[\mathrm{M}-2 \mathrm{H}]^{2-}$ ion for the hydrolysed product and each were fragmented using collision energy optimisation. The fragmentation results demonstrate that the structure of the ambiguous DP6 corresponds to a neo- $\beta-\mathrm{l}-\kappa$ hexasaccharide (Figure 3A), this is not completely unexpected as a 'non-negligible' amount of 1carrabiose moieties are present in furcellaran [36]. The exo-3,6-anhydro-D-galactosidase activity of $\mathrm{ZgGH} 129$ is therefore on the neo- $\beta$-carrageenan motif at the non-reducing end as confirmed by the MSMS analysis of the $\mathrm{m} / \mathrm{z} 526.0$ species (Figure 3B). This is in consensus with the enzyme's previously described inactivity on $\kappa$-carrageenan oligosaccharides [6]. These mass-spectrometry experiments, along with the previous experiments demonstrating inactivity on neo- $\kappa$-oligosaccharides, suggest $Z g \mathrm{GH} 129$ is specific for neo- $\beta$-carrageenan motifs at the non-reducing end. Furthermore, these results also demonstrate that $\mathrm{ZgGH} 129$ is capable of accommodating a sulfate group on the 2-hydroxyl of 3,6anhydro-D-galactose in its +2 sub-site and a 4-sulfo group on the D-galactose moiety in its predicted +3 sub-site (the neo-1-carrabiose motif) [6]. These results align with the suggested pathway of carrageenan degradation of Z. galactanivorans, where the GH129 enzyme acts on neo- $\beta$-carrabiose motifs after the action of the CarPUL carrageenases and sulfatases [6, 38].

\subsection{Synthesis of 4-nitrophenyl 3,6-anhydro- $\alpha$-D-galactopyranoside}

In general, synthetically derived substrates, possessing a leaving group that when hydrolysed can be followed spectrophotometrically, are ideal materials to identify and characterise enzymes of interest. A 
common class of substrates that are used to study glycosidases are the 4-nitrophenyl-based glycosides due to the release of 4-nitrophenolate which can be monitored spectrophotometrically. Therefore, the putative substrate 4-nitrophenyl 3,6-anhydro- $\alpha$-D-galactopyranoside (3,6-ADG- $p \mathrm{NP})$ was prepared as an artificial substrate for $Z g \mathrm{GH} 129$ (Scheme 1). The most efficient route to 3,6-ADG- $p$ NP would be via a ring closure of 4-nitrophenyl $\alpha$-D-galactopyranoside (Gal- $p \mathrm{NP}$ ), as this material is readily available commercially. One previously utilised method to form a 3,6-anhydro-bridge is to first prepare the 6-O-tosyl-glycoside, followed by treatment with a strong base [39, 40]. With this knowledge 4-nitrophenyl 6-O-tosyl- $\alpha$-Dgalactopyranoside (6-tosyl-Gal-pNP) was successfully obtained from Gal-pNP using the conditions of Siewert and Westphal [41]. However, when 6-tosyl-Gal-pNP was exposed to the strong basic conditions needed for the ring closure, (sodium methoxide) as done in previous 3,6-anhydro bond-forming reactions [39], the starting material was consumed but no formation of the desired 3,6-ADG- $p$ NP was observed. Instead the reaction mixture possessed a strong yellow colour which is conducive to the presence of 4nitrophenolate, indicating the 4-nitrophenyl group was being displaced under the reaction conditions. This is likely due to the 3,6-anhydro moiety which once installed results in additional ring strain and increased reactivity, causing instability of the compound under basic conditions [40]. An alternative method which does not expose the product to strongly basic conditions is a direct route which has previously been applied to methyl galactopyranosides $[42,43]$ which were subjected to Appel bromination reaction conditions and resulted in methyl 3,6-anhydro-galactopyranoside being formed as well as methyl 6bromo-6-deoxy-galactopyanoside as a significant side product. Pleasingly, using these conditions, but with Gal- $p$ NP, resulted in the successful isolation of the desired 3,6-ADG- $p$ NP substrate. The yield was low (45\%) and 4-nitrophenyl 6-bromo-6-deoxy- $\alpha$-D-galactopyranoside was also formed (26\%, 6-bromoGal- $p$ NP) (Scheme 1). The NMR and MS details for the novel compounds are described in the experimental section (4.4) and Supplementary File 2.

\subsection{Kinetic analyses of ZgGH129}


Determination of the $\mathrm{pH}$ optimum was done at the isosbestic point of 4-nitrophenol/4-nitrophenolate (348 $\mathrm{nm}$ ) first in universal buffer (Figure 4A), followed by a finer sampling in citrate buffer (Figure 4B) [44, 45] using 3,6-ADG- $p$ NP as the substrate. Both buffer systems confirmed the optimal activity of ZgGH129 to be $\mathrm{pH} 5$ and the enzyme activity was stable for the duration of these experiments. Of note though is that $\mathrm{ZgGH} 129$ is not stable stored in the citrate buffer at $\mathrm{pH} 5$ for extended periods as it precipitates almost entirely after an overnight dialysis. On the other hand, the enzyme can be stored refrigerated for months at a time in 1 x PBS or $50 \mathrm{mM}$ Tris $\mathrm{pH} 8$ and still retain its activity.

The predicted localisation of the $\mathrm{ZgGH} 129$ enzyme is periplasmic [6] (SignalP-5.0 [46], data not shown). In $E$. coli the $\mathrm{pH}$ in the periplasm is in the order of that outside the cell; challenges using rapid acid shift showed the periplasm reflected a similar $\mathrm{pH}$ as the extracellular milieu [47]. Conversely, in the cytoplasm there was a sharp drop in the $\mathrm{pH}$ upon acid treatment followed by a slow return towards baseline [47]. This suggests that the outer membrane is not a significant impediment to proton movement. If this hold true in Bacteroidetes, then the $\mathrm{pH}$ of the periplasm should be that of seawater. The surface seawater in the English channel has been measured at pH 8.28+0.01 in March 2008 and 8.09+0.01 in July 2008 [48], seawater $\mathrm{pH}$ can also vary with both location and temperature $[49,50]$. The $\mathrm{pH}$ optimum performed both in citrate and in universal buffer shows a slow decline in activity above $\mathrm{pH}$. The universal buffer $\mathrm{pH}$ curve shows activity at $\mathrm{pH} \mathrm{9,} \mathrm{albeit} \mathrm{considerably} \mathrm{lower} \mathrm{than} \mathrm{at} \mathrm{pH}$ 5. Furthermore, initial $\mathrm{ZgGH} 129$ assays on furcellaran oligosaccharides were successful at $\mathrm{pH} 7.5$ [6]. These results indicate that $Z g \mathrm{GH} 129$ maintains significant activity even several $\mathrm{pH}$ units away from the optimum. Altogether, these results suggest that $\mathrm{ZgGH} 129$ would be active within the periplasm of Z. galactanivorans at the $\mathrm{pH}$ of seawater.

Initial optimal temperature tests between $28{ }^{\circ} \mathrm{C}$ and $51{ }^{\circ} \mathrm{C}$ indicated that $\mathrm{ZgGH} 129$ preferred a higher temperature range (data not shown) thus a finer optimal temperature range was also performed in triplicate between $45{ }^{\circ} \mathrm{C}$ to $52{ }^{\circ} \mathrm{C}$ with the optimum temperature determined to be $49{ }^{\circ} \mathrm{C}$ (Figure $4 \mathrm{C}$ ). This 
result was unexpected as Z. galactanivorans was isolated from a red macroalga, Delesseria sanguinea, in the waters off Roscoff, France, on the English Channel [26]. The waters off Roscoff range in temperature from $9{ }^{\circ} \mathrm{C}$ in winter to a maximum of $18{ }^{\circ} \mathrm{C}$ in the summer [51]. At low tide, however, macroalgae are exposed to the elements and in sunny conditions the temperature on the surface of the algae rises appreciably [52]. An enzyme (e.g. ZgGH129) capable of activity at higher temperatures would be useful to the bacterium under these conditions. Stability of the enzyme was not investigated at the optimal temperature, though the enzyme remains viable for months at $4{ }^{\circ} \mathrm{C}$ when the appropriate buffer system is chosen.

To complement the temperature and $\mathrm{pH}$ optimum data obtained for $\mathrm{ZgGH} 129$, the Michaelis-Menten parameters were also determined (at the temperature and $\mathrm{pH}$ optimum) using 3,6-ADG- $p \mathrm{NP}$ as a substrate (Figure 4D). The $K_{\mathrm{m}}$ was determined to be $0.7 \pm 0.1 \mathrm{mM}$, the $\mathrm{k}_{\mathrm{cat}} 38.9 \pm 2.4 \mathrm{~s}^{-1}$ and the specificity constant $5.6 \pm 0.9 \times 10^{4} \mathrm{M}^{-1} \mathrm{~s}^{1}$. Analysis of the same data by Lineweaver-Burk plot produced similar results (not shown). Thus, $Z g G H 129$ shows robust activity on the artificial substrate 3,6-ADG- $p$ NP and demonstrates that this compound could have wider utility in elucidating exo-3,6-anhydro-D-galactosidase activity in biochemical assays. Overall, these kinetic characterisations provide a first mechanistic glimpse into a newly discovered enzyme activity. More experimentation is certainly needed to determine optimal parameters if the enzyme is to be exploited industrially to modify neo-carrageenan oligosaccharides.

\section{Conclusion}

Sulfated polysaccharides demonstrate a wide variety of bioactivities presumably due to their resemblance to metazoan sulfated sugars. The ability to tailor the physiochemical properties of these algal carbohydrates enzymatically is of strong biotechnological interest. The exo-( $\alpha-1,3)-3,6$-anhydro-Dgalactosidase activity is an activity only recently discovered [6], therefore there is strong fundamental 
interest to describe the biochemistry behind this newly discovered enzymatic activity within the GH129 family. The phylogenetic analyses demonstrate the GH129 family is divided into two niche-distinct clades, likely an example of a horizontal gene transfer event. Using natural oligo-carrageenan substrates and detailed mass spectrometry experiments, we have shown the marine Flavobacterium clade 2 member $\mathrm{ZgGH} 129$ cleaves the unique red algal 3,6-anhydro-D-galactose moiety from non-reducing end neo- $\beta$ -

carrabiose motifs. Furthermore, we have begun to decipher the sub-site preferences of the enzyme using these structural methods. Finally, we have developed a novel molecular tool, 3,6-ADG- $p$ NP, allowing us to perform a fine kinetic characterisation of exo-( $\alpha-1,3)-3,6$-anhydro-D-galactosidase enzyme activity. This artificial substrate will be useful for characterisation of other enzymes from clade 2 of the GH129 family and for the newly discovered exo-( $\alpha-1,3)-3,6$-anhydro-D-galactosidase activity within the GH127 family, whose characterised members are encoded in the same Flavobacterium CarPUL as ZgGH129 [6].

\section{Experimental procedures}

\subsection{Phylogeny}

GH129 sequences were selected by Blastp and using the CAZy databank [53]. Three GH101 characterised enzymes were chosen for the outgroup [30-32]. The amino acid sequences were aligned using MAFFT [54] with the L-INS-i algorithm and the alignment was manually refined using Bioedit [55]. The evolutionary history was inferred by using the Maximum Likelihood method and the Whelan And Goldman model [29]. Initial tree(s) for the heuristic search were obtained automatically by applying Neighbor-Join and BioNJ algorithms to a matrix of pairwise distances estimated using a JTT model, and then selecting the topology with superior log likelihood value. A discrete Gamma distribution was used to model evolutionary rate differences among sites [5 categories $(+\mathrm{G}$, parameter $=4.2144)]$. The tree was drawn to scale, with branch lengths measured in the number of substitutions per site. This analysis 
involved 100 enzyme sequences from different bacterial species. There were a total of 526 amino acid positions in the final dataset. Evolutionary analyses were conducted in MEGA X [56].

\subsection{Protein production and purifications}

The pFO4 plasmid containing the zgal_3152 gene fragment [6] was transformed into Escherichia coli BL21(DE3) and grown in $1 \mathrm{~L}$ of autoinduction Zyp-5052 media $\left(200 \mu \mathrm{g} \mathrm{mL}{ }^{-1}\right.$ ampicillin, $\left.20{ }^{\circ} \mathrm{C}\right)$. Cells were harvested by centrifugation at $3063 \times \mathrm{g}$ for $30 \mathrm{~min}$ and lysed by chemical lysis [57]. The lysate was clarified at $13,865 \times \mathrm{g}$ for $45 \mathrm{~min}$ at $4{ }^{\circ} \mathrm{C}$. The supernatant was loaded onto a $5 \mathrm{~mL}$ GE His Trap HP column (part of an ÄKTA FPLC), washed with 1x PBS pH 7.4 and eluted with an increasing gradient of 1-100\% 1x PBS pH 7.4 containing $1 \mathrm{M}$ imidazole. Fractions containing the protein of interest were pooled and concentrated (MWCO $5 \mathrm{kDa}$ ). It is necessary to maintain recombinant $Z g \mathrm{GH} 129$ in a buffer that is above $\mathrm{pH} 7$ as the enzyme precipitates when stored at $\mathrm{pH}$. The experimentally obtained $\mathrm{pH}$ optimum is not an ideal $\mathrm{pH}$ for the storage of recombinant $\mathrm{ZgGH} 129$. The ExPASy ProtParam tool [58] was used to generate the extinction coefficient for calculation of protein concentration using A280.

\subsection{Mass spectroscopy}

\subsubsection{Enzyme reactions for mass spectroscopy experiments}

Substrates were produced from the polysaccharide furcellaran, obtained as a generous gift from CP Kelco (Brian Rudolph), from the red alga Furcellaria lumbricalis [6]. Furcellaran oligosaccharides were produced as described previously $[6,36]$ using the recombinant $\kappa$-carrageenase from Pseudoalteromonas carrageenovora [59].

\subsubsection{Matrix assisted laser desorption ionisation-Time of flight-MS analysis}


MALDI-TOF-MS spectra were acquired in negative ionisation mode and reflector detection in the $\mathrm{m} / \mathrm{z}$ range 500-1500 on an AutoflexSpeed TOF/TOF mass spectrometer (Bruker Daltonics, Bremen, Germany), equipped with a Smartbeam Laser $(355 \mathrm{~nm}, 1000 \mathrm{~Hz})$. Samples were analysed at a concentration of $500 \mu \mathrm{g} \cdot \mathrm{mL}^{-1}$ using DMA-DHB as a matrix as described in Ropartz et al. [37]. An external calibration using a mixture of carrageenan standards was used. Acquisition parameters (laser power, pulsed ion extraction, etc.) were optimised on the sample without any enzyme process. Spectra were recorded using FlexControl 3.4.

\subsubsection{Electrospray-quadripole- Time of flight-collision induced dissociation-MSMS analysis}

ESI-q-TOF Tandem MS experiments were performed in negative ion mode on a Synapt G2Si HDMS (Waters, Manchester, UK) in the $m / z$ range 150-1600. Samples were diluted in $\mathrm{MeOH} / \mathrm{H}_{2} \mathrm{O}(1: 1$, v/v) at 5 $\mu \mathrm{g} \mathrm{mL}-1$ and infused at a flow rate of $5 \mu \mathrm{L} \mathrm{min}{ }^{-1}$. The capillary voltage was set at $2.2 \mathrm{kV}$ and the source temperature at $120^{\circ} \mathrm{C}$. Candidate ions were fragmented with an optimized collision energy by CID in the transfer cell of the instrument using Argon as collision gas. Data were recorded using MassLynx 4.1 (Waters, Manchester, UK).

\subsubsection{MS data processing}

MALDI MS and ESI-q-TOF tandem MS raw data were converted in mzML format using MSConvert 3.0.18261 (http://proteowizard.sourceforge.net/downloads.shtml) and peak peaking was performed using mMass 5.5.037. For MSMS spectra annotation, the nomenclature of Domon and Costello was used [60].

\subsection{Synthesis of 4-nitrophenyl 3,6-anhydro- $\alpha$-D-galactopyranoside (3,6-ADG-pNP)}


General - All reagents and materials were purchased from commercial suppliers. Thin layer chromatography (TLC) used to monitor the reaction, was effected on Merck silica gel 60 F254 aluminium-backed plates and spots stained by heating with $5 \%$ conc. $\mathrm{H}_{2} \mathrm{SO}_{4}$ in ethanol. Flash column chromatography was performed on Merck silica gel using the specified solvents. NMR spectra were obtained on a Bruker Avance IIIHD 600 spectrometer, with DMSO- $d_{6}$ or $\mathrm{CD}_{3} \mathrm{OD}$ as solvents with $\mathrm{CD}_{3} \mathrm{~S}(\mathrm{O}) \mathrm{CD}_{2} \mathrm{H}\left({ }^{1} \mathrm{H}, \delta 2.50 \mathrm{ppm}\right),\left(\mathrm{CD}_{3}\right)_{2} \mathrm{SO}\left({ }^{13} \mathrm{C}, \delta 39.52 \mathrm{ppm}\right), \mathrm{CD}_{2} \mathrm{HOD}\left({ }^{1} \mathrm{H}, \delta 3.31 \mathrm{ppm}\right)$ or $\mathrm{CD}_{3} \mathrm{OD}$ $\left({ }^{13} \mathrm{C}, \delta 49.00 \mathrm{ppm}\right)$ used as an internal standard. Infrared spectra were obtained with neat samples on a PerkinElmer spectrum one FT-IR spectrometer fitted with a PerkinElmer Universal Attenuated Total Reflectance (ATR) sampling accessory. Infrared spectra annotated as strong (s), medium (m), weak (w) or broad (br) absorption band. High resolution mass spectra (HR-MS) were obtained on a Waters LCT Premier XE spectrometer, run in W-mode, using the ESI equipped ion source, in negative mode.

4-Nitrophenyl 3,6-anhydro- $\alpha$-D-galactopyranoside (3,6-ADG-pNP) and 4-nitrophenyl 6-bromo-6-deoxy-

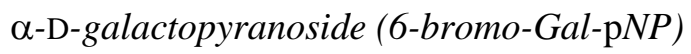

Carbon tetrabromide $(110 \mathrm{mg}, 0.33 \mathrm{mmol})$ and triphenylphosphine $(174 \mathrm{mg}, 0.66 \mathrm{mmol})$ were added to a stirred solution of 4-nitrophenyl $\alpha$-D-galactopyranoside $(100 \mathrm{mg}, 0.33 \mathrm{mmol})$ in pyridine $(2.5 \mathrm{ml})$ at $0{ }^{\circ} \mathrm{C}$. The resulting yellow solution was then stirred at $60{ }^{\circ} \mathrm{C}$ for $2.5 \mathrm{~h}$ and after this time was quenched with methanol at $0{ }^{\circ} \mathrm{C}$ and concentrated. The resulting residue was purified by flash column chromatography (MeOH:CHCl${ }_{3}$ 1:19) to obtain 3,6-ADG-pNP as a white solid (42 mg, 45\%). $\mathrm{R}_{\mathrm{f}}=0.43\left(\mathrm{MeOH}: \mathrm{CHCl}_{3}\right.$ 1:9). ${ }^{1} \mathrm{H}$ NMR (600 MHz, $\left.\left(\mathrm{CD}_{3}\right)_{2} \mathrm{SO}\right): \delta 8.22-8.18(\mathrm{~m}, 2 \mathrm{H}), 7.28-7.23(\mathrm{~m}, 2 \mathrm{H}), 5.57(\mathrm{~d}, J=2.6 \mathrm{~Hz}, 1 \mathrm{H})$, $5.51(b r \mathrm{~s}, 1 \mathrm{H}), 5.29(b r \mathrm{~s}, 1 \mathrm{H}), 4.38(b r \mathrm{~s}, 1 \mathrm{H}), 4.25-4.22(\mathrm{~m}, 1 \mathrm{H}), 4.22(\mathrm{~d}, J=5.2 \mathrm{~Hz}, 1 \mathrm{H}), 4.12(\mathrm{~d}$, $J=5.2 \mathrm{~Hz}, 1 \mathrm{H}), 3.99-3.95(\mathrm{~m}, 1 \mathrm{H}), 3.91(\mathrm{dd}, J=10.0,2.9 \mathrm{~Hz}, 1 \mathrm{H}) ;{ }^{13} \mathrm{C} \mathrm{NMR}\left(150.9 \mathrm{~Hz},\left(\mathrm{CD}_{3}\right)_{2} \mathrm{SO}\right): \delta$ 161.7, 141.7, 125.7, 116.6, 94.1, 81.1, 77.5, 69.2, 69.1, 68.3; FTIR (ATR): v = 3310 (br), 1611 (w), 1591 (m), 1509 (m) cm $\mathrm{cm}^{-1}$; HR-MS (ESI-): $\mathrm{m} / 2$ [M+HCOO] ${ }^{-}$calcd. for $\mathrm{C}_{13} \mathrm{H}_{14} \mathrm{NO}_{9}$ : 328.0669, found: 328.0668 . Next to elute was 6-bromo-Gal-pNP as a white solid (31 mg, 26\%). $\mathrm{R}_{\mathrm{f}}=0.34\left(\mathrm{MeOH}: \mathrm{CHCl}_{3}\right.$ 1:9). 
${ }^{1} \mathrm{H}$ NMR $\left(600 \mathrm{MHz}, \mathrm{CD}_{3} \mathrm{OD}\right): \delta 8.23-8.19(\mathrm{~m}, 2 \mathrm{H}), 7.35-7.32(\mathrm{~m}, 2 \mathrm{H}), 5.68(\mathrm{~d}, J=3.5 \mathrm{~Hz}, 1 \mathrm{H}), 4.05-$ $4.03(\mathrm{~m}, 1 \mathrm{H}), 4.02-3.95(\mathrm{~m}, 3 \mathrm{H}), 3.55(\mathrm{dd}, J=10.5,5.2 \mathrm{~Hz}, 1 \mathrm{H}), 3.47(\mathrm{dd}, J=10.5,8.0 \mathrm{~Hz}, 1 \mathrm{H})$; ${ }^{13} \mathrm{C}$ NMR $\left(150.9 \mathrm{~Hz}, \mathrm{CD}_{3} \mathrm{OD}\right): \delta 163.5,143.9,126.5,118.2,99.4,73.9,71.0,70.9,69.3,31.3$; FTIR (ATR): $v=3485$ (br), 1611 (w) 1591 (m), 1508 (s), 1493 (s) cm ${ }^{-1}$; HR-MS (ESI-): m/z [M-H] calculated. for $\mathrm{C}_{12} \mathrm{H}_{13} \mathrm{NO}_{7}{ }^{79} \mathrm{Br}: 361.9875$, found: 361.9885 .

\subsection{Enzyme Kinetics}

All reactions were done in triplicate and measured on a Spark microplate reader available through the Genomer platform at the Station Biologique de Roscoff. For determining Michaelis-Menten parameters reactions were set up using between 0 to $1.5 \mathrm{mM}$ 3,6-ADG- $p \mathrm{NP}, 5 \mathrm{nM} Z g \mathrm{GH} 129,0.1 \mathrm{M} \mathrm{NaOAc} \mathrm{pH}$, $0.1 \mathrm{M} \mathrm{CaCl}_{2}$ in a $49{ }^{\circ} \mathrm{C}$ water bath. An aliquot of $150 \mu \mathrm{L}$ of the reaction was taken at the 1,2 and 3minute mark, the linear period on the curve, with the reaction stopped by the addition of $75 \mu \mathrm{L}$ of $1 \mathrm{M}$ glycine $\mathrm{pH}$ 10.88. Spectrophotometric reads were taken immediately at $405 \mathrm{~nm}$ to measure 4-nitrophenolate production. Steady state Michaelis-Menten parameters were determined by non-linear curve fitting using Origin version 7 and by Lineweaver-Burk plot (not shown).

\subsection{Determination of optimal $\mathrm{pH}$ and temperature}

The $\mathrm{pH}$ optimum for $\mathrm{ZgGH} 129$ was determined first in Universal buffer $[61,62]$ between $\mathrm{pH} 2-8$ using $20 \mathrm{~mL}$ of stock solution of $50 \mathrm{mM} \mathrm{Na} 2 \mathrm{HPO}_{4}, 33 \mathrm{mM}$ citric acid, $50.7 \mathrm{mM}$ boric acid, $243 \mathrm{mM} \mathrm{NaOH}$ which was diluted down with appropriate amounts of $0.1 \mathrm{M} \mathrm{HCl}$ for the desired $\mathrm{pH}$ and topped up to 100 $\mathrm{mL}$ with water. The reactions were set up in triplicate at $25^{\circ} \mathrm{C}$ in a volume of $150 \mu \mathrm{L}$ with $144.6 \mu \mathrm{L}$ of the diluted stock solution at the desired pH, $1 \mathrm{mM}$ 3,6-ADG-pNP, and $184.8 \mathrm{nM}$ of $Z g \mathrm{GH} 129$. A second $\mathrm{pH}$ curve was determined with reactions set up in triplicate in a volume of $150 \mu \mathrm{L}$ with $144.6 \mu \mathrm{L}$ of $50 \mathrm{mM}$ 
citrate buffer between $\mathrm{pH}$ 3-7, $1 \mathrm{mM}$ 3,6-ADG-pNP, and $177.6 \mathrm{nM}$ of $\mathrm{ZgGH} 129$. Continuous reads were collected spectrophotometrically at the isosbestic point of 4-nitrophenol/4-nitrophenolate (348 nm). For determining optimal temperature reactions $(150 \mu \mathrm{L})$ contained $5 \mathrm{nM}$ of $\mathrm{ZgGH} 129,0.25 \mathrm{mM}$ 3,6-ADG$p \mathrm{NP}, 1.3 \mathrm{mM} \mathrm{CaCl}_{2}$ and $50 \mathrm{mM}$ sodium acetate buffer $\mathrm{pH}$ 5. Reactions were stopped with $75 \mu \mathrm{L} 1 \mathrm{M}$ glycine at $\mathrm{pH}$ 10.88. Stopped reads were read spectrophotometrically at $405 \mathrm{~nm}$ and the rate of reaction was determined using the 4-nitrophenolate extinction coefficient of $18.5 \mathrm{M}^{-1} \mathrm{~cm}^{-1}$.

\section{Data Availability}

The detailed phylogenetic tree can be found in Supplementary File 1 . The ${ }^{1} \mathrm{H}$ and ${ }^{13} \mathrm{C}$ NMR spectra of synthesised compounds is also found in Supplementary File 2.

\section{Acknowledgements}

Mass spectrometry analyses were conducted by the IBiSA platform "Biopolymers-Structural Biology" located at the INRA Center of Nantes (INRA Research Unit 1268 BIA) http://www.bibs.inra.fr. We thank the Genomer platform at the Station Biologique de Roscoff for use of their equipment. EF-B acknowledges support from the Agence National de la Recherche (ANR) for the "Blue Enzymes" project (reference ANR-14-CE19-0020-01). The authors acknowledge the facilities, and the scientific and technical assistance of the Microscopy Australia at the Centre for Microscopy, Characterisation and Analysis, The University of Western Australia, a facility funded by the University, State and Federal Commonwealth Governments. MDW is supported by a Research Training Program Scholarship provided by the Australian Federal Government and The University of Western Australia. MDW also thanks The University of Western Australia School of Molecular Sciences for the Dr Wayne Best Travel Award, and Campus France and the Franco-Australian Hubert Curien Programme (FASIC) for funding, which 
together funded the travel of MDW to the Station Biologique de Roscoff. KAS also thanks the Australian Research Council for funding (FT100100291).

\section{References}

[1] J.P. Gattuso, M. Frankignoulle, R. Wollast, Carbon and carbonate metabolism in coastal aquatic ecosystems, Annual Review of Ecology and Systematics 29 (1998) 405-434.

[2] E. Ficko-Blean, Hervé, C., Michel, G., Sweet and sour sugars from the sea: the biosynthesis and remodeling of sulfated cell wall polysaccharides from marine macroalgae, PiP 2 (2015) 51-64.

[3] M. Lahaye, Marine algae as sources of fibres: determination of soluble and insoluble dietary fibre contents in some 'sea vegetables' J Sci Food Agr 54 (1991) 587-594.

[4] D.H. Ngo, S.K. Kim, Sulfated polysaccharides as bioactive agents from marine algae, Int J Biol Macromol 62 (2013) 70-75.

[5] F. Cuskin, E.C. Lowe, M.J. Temple, Y. Zhu, E.A. Cameron, N.A. Pudlo, N.T. Porter, K. Urs, A.J. Thompson, A. Cartmell, A. Rogowski, B.S. Hamilton, R. Chen, T.J. Tolbert, K. Piens, D. Bracke, W. Vervecken, Z. Hakki, G. Speciale, J.L. Munoz-Munoz, A. Day, M.J. Pena, R. McLean, M.D. Suits, A.B. Boraston, T. Atherly, C.J. Ziemer, S.J. Williams, G.J. Davies, D.W. Abbott, E.C. Martens, H.J. Gilbert, Human gut Bacteroidetes can utilize yeast mannan through a selfish mechanism, Nature 517(7533) (2015) 165-169.

[6] E. Ficko-Blean, A. Prechoux, F. Thomas, T. Rochat, R. Larocque, Y. Zhu, M. Stam, S. Genicot, M. Jam, A. Calteau, B. Viart, D. Ropartz, D. Perez-Pascual, G. Correc, M. Matard-Mann, K.A. Stubbs, H. Rogniaux, A. Jeudy, T. Barbeyron, C. Medigue, M. Czjzek, D. Vallenet, M.J. McBride, E. Duchaud, G. Michel, Carrageenan catabolism is encoded by a complex regulon in marine heterotrophic bacteria, Nat Commun 8(1) (2017) 1685.

[7] J. Larsbrink, T.E. Rogers, G.R. Hemsworth, L.S. McKee, A.S. Tauzin, O. Spadiut, S. Klinter, N.A. Pudlo, K. Urs, N.M. Koropatkin, A.L. Creagh, C.A. Haynes, A.G. Kelly, S.N. Cederholm, G.J. Davies, 
E.C. Martens, H. Brumer, A discrete genetic locus confers xyloglucan metabolism in select human gut Bacteroidetes, Nature 506(7489) (2014) 498-502.

[8] A.G. Hettle, J.K. Hobbs, B. Pluvinage, C. Vickers, K.T. Abe, O. Salama-Alber, B.E. McGuire, J.H. Hehemann, J.P.M. Hui, F. Berrue, A. Banskota, J. Zhang, E.M. Bottos, J. Van Hamme, A.B. Boraston, Insights into the kappa/iota-carrageenan metabolism pathway of some marine Pseudoalteromonas species, Commun Biol 2(1) (2019) 474.

[9] J.M. Grondin, K. Tamura, G. Dejean, D.W. Abbott, H. Brumer, Polysaccharide Utilization Loci: Fueling Microbial Communities, J Bacteriol 199(15) (2017) e00860-16.

[10] P. Sheridan, J.C. Martin, T.D. Lawley, H.P. Browne, H.M.B. Harris, A. Bernalier-Donadille, S.H. Duncan, P.W. O'Toole, K. Scott, H. Flint, Polysaccharide utilization loci and nutritional specialization in a dominant group of butyrate-producing human colonic Firmicutes, Microb Genom 2(2) (2016) e000043. [11] G. Dejean, S. Blanvillain-Baufume, A. Boulanger, A. Darrasse, T. Duge de Bernonville, A.L. Girard, S. Carrere, S. Jamet, C. Zischek, M. Lautier, M. Sole, D. Buttner, M.A. Jacques, E. Lauber, M. Arlat, The xylan utilization system of the plant pathogen Xanthomonas campestris pv campestris controls epiphytic life and reveals common features with oligotrophic bacteria and animal gut symbionts, New Phytol 198(3) (2013) 899-915.

[12] K.L. Anderson, A.A. Salyers, Genetic evidence that outer membrane binding of starch is required for starch utilization by Bacteroides thetaiotaomicron, J Bacteriol 171(6) (1989) 3199-204.

[13] K.L. Anderson, A.A. Salyers, Biochemical evidence that starch breakdown by Bacteroides thetaiotaomicron involves outer membrane starch-binding sites and periplasmic starch-degrading enzymes, J Bacteriol 171(6) (1989) 3192-8.

[14] V. Lombard, H. Golaconda Ramulu, E. Drula, P.M. Coutinho, B. Henrissat, The carbohydrate-active enzymes database (CAZy) in 2013, Nucleic Acids Res 42(1) (2014) D490-495.

[15] L. Reisky, A. Prechoux, M.K. Zuhlke, M. Baumgen, C.S. Robb, N. Gerlach, T. Roret, C. Stanetty, R. Larocque, G. Michel, T. Song, S. Markert, F. Unfried, M.D. Mihovilovic, A. Trautwein-Schult, D. 
Becher, T. Schweder, U.T. Bornscheuer, J.H. Hehemann, A marine bacterial enzymatic cascade degrades the algal polysaccharide ulvan, Nat Chem Biol 15(8) (2019) 803-812.

[16] F. Thomas, P. Bordron, D. Eveillard, G. Michel, Gene expression analysis of Zobellia galactanivorans during the degradation of algal polysaccharides reveals both substrate-specific and shared transcriptome-wide responses, Front Microbiol 8 (2017) 1808.

[17] F. Thomas, T. Barbeyron, T. Tonon, S. Genicot, M. Czjzek, G. Michel, Characterization of the first alginolytic operons in a marine bacterium: from their emergence in marine Flavobacteriia to their independent transfers to marine Proteobacteria and human gut Bacteroides, Environ Microbiol 14(9) (2012) 2379-2394.

[18] A. Gobet, T. Barbeyron, M. Matard-Mann, G. Magdelenat, D. Vallenet, E. Duchaud, G. Michel, Evolutionary evidence of algal polysaccharide degradation acquisition by Pseudoalteromonas carrageenovora 9(T) to adapt to macroalgal niches, Front Microbiol 9 (2018) 2740.

[19] L. Christiansen, D. Pathiraja, P.K. Bech, M. Schultz-Johansen, R. Hennessy, D. Teze, I.G. Choi, P. Stougaard, A multifunctional polysaccharide utilization gene cluster in Colwellia echini encodes enzymes for the complete degradation of kappa-carrageenan, iota-carrageenan, and hybrid beta/kappa-carrageenan, mSphere 5(1) (2020).

[20] S. Genicot-Joncour, A. Poinas, O. Richard, P. Potin, B. Rudolph, B. Kloareg, W. Helbert, The cyclization of the 3,6-anhydro-galactose ring of iota-carrageenan is catalyzed by two D-galactose-2,6sulfurylases in the red alga Chondrus crispus, Plant Physiol 151(3) (2009) 1609-16.

[21] M. Guibet, S. Colin, T. Barbeyron, S. Genicot, B. Kloareg, G. Michel, W. Helbert, Degradation of lambda-carrageenan by Pseudoalteromonas carrageenovora lambda-carrageenase: a new family of glycoside hydrolases unrelated to kappa- and iota-carrageenases, Biochem J 404(1) (2007) 105-14.

[22] G. Michel, P. Nyval-Collen, T. Barbeyron, M. Czjzek, W. Helbert, Bioconversion of red seaweed galactans: a focus on bacterial agarases and carrageenases, Appl Microbiol Biotechnol 71(1) (2006) 2333. 
[23] G. Michel, L. Chantalat, E. Duee, T. Barbeyron, B. Henrissat, B. Kloareg, O. Dideberg, The kappacarrageenase of $P$. carrageenovora features a tunnel-shaped active site: a novel insight in the evolution of Clan-B glycoside hydrolases, Structure 9(6) (2001) 513-25.

[24] T. Barbeyron, G. Michel, P. Potin, B. Henrissat, B. Kloareg, Iota-carrageenases constitute a novel family of glycoside hydrolases, unrelated to that of kappa-carrageenases, J Biol Chem 275(45) (2000) $35499-505$.

[25] T. Barbeyron, F. Thomas, V. Barbe, H. Teeling, C. Schenowitz, C. Dossat, A. Goesmann, C. Leblanc, F. Oliver Glockner, M. Czjzek, R. Amann, G. Michel, Habitat and taxon as driving forces of carbohydrate catabolism in marine heterotrophic bacteria: example of the model algae-associated bacterium Zobellia galactanivorans Dsij(T), Environ Microbiol 18(12) (2016) 4610-4627.

[26] T. Barbeyron, S. L'Haridon, E. Corre, B. Kloareg, P. Potin, Zobellia galactanovorans gen. nov., sp nov., a marine species of Flavobacteriaceae isolated from a red alga, and classification of [Cytophaga] uliginosa (ZoBell and Upham 1944) Reichenbach 1989 as Zobellia uliginosa gen. nov., comb. nov., International journal of systematic and evolutionary microbiology 51 (2001) 985-997.

[27] M. Kiyohara, T. Nakatomi, S. Kurihara, S. Fushinobu, H. Suzuki, T. Tanaka, S. Shoda, M. Kitaoka, T. Katayama, K. Yamamoto, H. Ashida, alpha-N-acetylgalactosaminidase from infant-associated bifidobacteria belonging to novel glycoside hydrolase family 129 is implicated in alternative mucin degradation pathway, J Biol Chem 287(1) (2012) 693-700.

[28] M. Sato, D. Liebschner, Y. Yamada, N. Matsugaki, T. Arakawa, S.S. Wills, M. Hattie, K.A. Stubbs, T. Ito, T. Senda, H. Ashida, S. Fushinobu, The first crystal structure of a family 129 glycoside hydrolase from a probiotic bacterium reveals critical residues and metal cofactors, J Biol Chem 292(29) (2017) 12126-12138.

[29] S. Whelan, N. Goldman, A general empirical model of protein evolution derived from multiple protein families using a maximum-likelihood approach, Mol Biol Evol 18(5) (2001) 691-699. 
[30] K.J. Gregg, M.D. Suits, L. Deng, D.J. Vocadlo, A.B. Boraston, Structural analysis of a family 101 glycoside hydrolase in complex with carbohydrates reveals insights into its mechanism, J Biol Chem 290(42) (2015) 25657-69.

[31] K. Fujita, F. Oura, N. Nagamine, T. Katayama, J. Hiratake, K. Sakata, H. Kumagai, K. Yamamoto, Identification and molecular cloning of a novel glycoside hydrolase family of core 1 type O-glycanspecific endo-alpha-N-acetylgalactosaminidase from Bifidobacterium longum, J Biol Chem 280(45) (2005) 37415-22.

[32] M.E. Caines, H. Zhu, M. Vuckovic, L.M. Willis, S.G. Withers, W.W. Wakarchuk, N.C. Strynadka, The structural basis for T-antigen hydrolysis by Streptococcus pneumoniae: a target for structure-based vaccine design, J Biol Chem 283(46) (2008) 31279-83.

[33] J.H. Kim, B.H. Choi, M. Jo, S.C. Kim, P.C. Lee, Flavobacterium faecale sp. nov., an agaraseproducing species isolated from stools of Antarctic penguins, International journal of systematic and evolutionary microbiology 64(Pt 8) (2014) 2884-90.

[34] B.T. Tierney, Z. Yang, J.M. Luber, M. Beaudin, M.C. Wibowo, C. Baek, E. Mehlenbacher, C.J. Patel, A.D. Kostic, The landscape of genetic content in the gut and oral human microbiome, Cell Host Microbe 26(2) (2019) 283-295 e8.

[35] J.H. Hehemann, G. Correc, T. Barbeyron, W. Helbert, M. Czjzek, G. Michel, Transfer of carbohydrate-active enzymes from marine bacteria to Japanese gut microbiota, Nature 464(7290) (2010) 908-12.

[36] G. Correc, A. Barabanova, R. Tuvikene, K. Truus, I. Yermak, W. Helbert, Comparison of the structures of hybrid kappa-/beta-carrageenans extracted from Furcellaria lumbricalis and Tichocarpus crinitus, Carbohyd Polym 88(1) (2012) 31-36.

[37] D. Ropartz, P.E. Bodet, C. Przybylski, F. Gonnet, R. Daniel, M. Fer, W. Helbert, D. Bertrand, H. Rogniaux, Performance evaluation on a wide set of matrix-assisted laser desorption ionization matrices for the detection of oligosaccharides in a high-throughput mass spectrometric screening of carbohydrate depolymerizing enzymes, Rapid Commun Mass Spectrom 25(14) (2011) 2059-70. 
[38] T. Barbeyron, L. Brillet-Gueguen, W. Carre, C. Carriere, C. Caron, M. Czjzek, M. Hoebeke, G. Michel, Matching the diversity of sulfated biomolecules: Creation of a classification database for sulfatases reflecting their substrate specificity, PLoS One 11(10) (2016) e0164846.

[39] A. Rashid, W. Mackie, Efficient and stereoselective synthesis of methyl 3-O-(3,6-anhydro-beta-Dgalactopyranosyl)-alpha-D-galactopyranoside and methyl 3,6-anhydro-4-O-beta-D-galactopyranosylalpha-D-galactopyranoside, Carbohydr Res 223 (1992) 147-55.

[40] W.N. Haworth, J. Jackson, F. Smith, The properties of 3 : 6-anhydrogalactose., J Chem Soc 115 (1940) 620-632.

[41] G. Siewert, O. Westphal, Synthesis of mono- and dideoxy-derivatives of p-aminophenyl-alpha-Dgalactopyranose, Justus Liebigs Annalen der Chemie 720 (1969) 188-197.

[42] G.O. Aspinall, R.C. Carpenter, L. Khondo, Formation of 6-deoxy-6-iodohexopyranosides as substrates for the hex-5-enose degradation., Carb Res 165 (1987) 281-298.

[43] C.J. France, I.M. McParlane, C.G. Newton, P. Pitchen, D.H.R. Barton, Bis-deoxygenation of methyl 3,6-anhydro-D-pyranosides. , Tetrahedron 32 (1991) 6381-6388.

[44] M. Hriscu, L. Chiş, M. Tosa, F.D. Irimie, pH-profiling of thermoactive lipases and esterases: Caveats and further notes, Eur J Lipid Sci Technol 115 (2013) 571-575.

[45] A.I. Biggs, A spectrophotometric determination of the dissociation constants of $p$-nitrophenol and papaverine, Transactions of the Faraday Society 50 (1954) 800-802.

[46] J.J. Almagro Armenteros, K.D. Tsirigos, C.K. Sonderby, T.N. Petersen, O. Winther, S. Brunak, G. von Heijne, H. Nielsen, SignalP 5.0 improves signal peptide predictions using deep neural networks, Nat Biotechnol 37(4) (2019) 420-423.

[47] J.C. Wilks, J.L. Slonczewski, pH of the cytoplasm and periplasm of Escherichia coli: rapid measurement by green fluorescent protein fluorimetry, J Bacteriol 189(15) (2007) 5601-7.

[48] N.J. Wyatt, V. Kitidis, E.M.S. Woodward, A.P. Rees, S. Widdicombe, M. Lohan, Effects of high $\mathrm{CO} 2$ on the fixed nitrogen inventory of the Western English Channel, J Plankton Res 32(5) (2009) 631-

641. 
[49] D. Clark, M. Lamare, M. Barker, Response of sea urchin pluteus larvae (Echinodermata:

Echinoidea) to reduced seawater $\mathrm{pH}$ : a comparison among a tropical, temperate, and a polar species, Mar Biol 156 (2009) 1125-1137.

[50] F.J. Millero, J.-Z. Zhang, S. Fiol, S. Sotolongo, R.N. Roy, K. Lee, S. Mane, The use of buffers to measure the $\mathrm{pH}$ of seawater, Marine Chemistry 44 (1993) 143-152.

[51] Global Sea Temperature. https://www.seatemperature.org/europe/france/roscoff.htm.

[52] E.C. Bell, Environmental and morphological influences on thallus temperature and desiccation of the intertidal alga Mastocarpus papillatus Kützing, Journal of experimental marine biology and ecology 191(1) (1995) 29-55.

[53] B. Henrissat, A classification of glycosyl hydrolases based on amino acid sequence similarities, Biochem J 280 (1991) 309-316.

[54] K. Katoh, D.M. Standley, MAFFT multiple sequence alignment software version 7: improvements in performance and usability, Mol Biol Evol 30(4) (2013) 772-780.

[55] T. Hall, BioEdit: a user-friendly biological sequence alignment editor and analysis program for Windows 95/98/NT, Nucl. Acids. Symp. Ser. 41 (1999) 95-98.

[56] S. Kumar, G. Stecher, M. Li, C. Knyaz, K. Tamura, MEGA X: molecular evolutionary genetics analysis across computing platforms, Mol Biol Evol 35(6) (2018) 1547-1549.

[57] E. Ficko-Blean, D. Duffieux, E. Rebuffet, R. Larocque, A. Groisillier, G. Michel, M. Czjzek, Biochemical and structural investigation of two paralogous glycoside hydrolases from Zobellia galactanivorans: novel insights into the evolution, dimerization plasticity and catalytic mechanism of the GH117 family, Acta Crystallogr D Biol Crystallogr 71(Pt 2) (2015) 209-23.

[58] E. Gasteiger, C. Hoogland, A. Gattiker, S. Duvaud, M.R. Wilkins, R.D. Appel, A. Bairoch, Protein identification and analysis tools on the ExPASy server, in: J.M. Walker (Ed.)2005, pp. 571-607

[59] G. Michel, T. Barbeyron, D. Flament, T. Vernet, B. Kloareg, O. Dideberg, Expression, purification, crystallization and preliminary x-ray analysis of the kappa-carrageenase from Pseudoalteromonas carrageenovora, Acta Crystallogr D Biol Crystallogr 55 (1999) 918-920. 
[60] B. Domon, C.E. Costello, Structure elucidation of glycosphingolipids and gangliosides using highperformance tandem mass spectrometry, Biochemistry 27(5) (1988) 1534-43.

[61] T. Teorell, E. Stenhagen, Biochem Z 299 (1938) 416.

[62] S. Ostling, P. Virtama, A modified preparation of the universal buffer described by Teorell and Stenhagen, Acta Physiol Scand 11 (1946) 289-293. 


\section{Figures}

Figure 1. Substrate specificity of exo-( $\alpha-1,3)-3,6$-anhydro-D-galactosidases and their relationship to other enzymes in the GH129 family. (A) The structures of exo-neo- $\beta$-carrabiose and endo-neo- $\kappa-$ and endo-neo1-carrabiose, which contain the individual monosaccharides 3,6-anhydro- $\alpha$-D-galactose (3,6-ADG) and Dgalactose (D-Gal). The molecules differ in structure due to the degree of sulfation (levels $\beta<\kappa<1$ ). The exo-neo- $\beta$-motif and bond that is cleaved by $Z g G H 129$ is shown in neo- $\beta$-carrabiose. (B) Structural overlap of the active sites of the two characterised members of GH129. BbGH129 [pdb id 5wzn [28]] is shown in green in complex with GalNAc in teal. ZgGH129 [pdb id 5opq [6]] is shown in salmon for one monomer with the amino acids from the other monomer shown in yellow. Calcium from BbGH129 is depicted as a maroon sphere. (C) Phylogenetic tree of the GH129 family of glycoside hydrolases with three GH101 enzymes chosen for the outgroup [30-32]. The amino acid sequences were aligned using MAFFT [54] with the L-INS-i algorithm and the alignment was manually refined using BioEdit [55]. The evolutionary history was inferred by using the Maximum Likelihood method and Whelan And Goldman model [29] in MEGA X [56]. The conformations of the substrates, 3,6-ADG and GalNAc, for the different clade enzymes illustrates the differences between the two enzyme activities.

Figure 2. Characterization of the carrageenan oligosaccharides released from enzymatic digestion by MALDI-TOF-MS measurement in negative ionisation mode. (A) Initial oligosaccharides released by the א-carrageenase enzymatic activity from Pseudoalteromonas carrageenovora [23] and (B) followed by the action of $Z g G H 129$. The oligosaccharides resulting from the activity of $Z g G H 129$ are indicated by arrows. The oligosaccharides attributed to sulfate loss during the experiment are labeled.

Figure 3. Structural characterization of $\beta-1-\kappa$ DP6 oligosaccharide and its enzymatic products obtained by ESI-q-TOF-MSMS analysis in negative ionisation mode. The upper spectrum (A) was obtained by 
isolating the $[\mathrm{M}-3 \mathrm{H}+\mathrm{Na}]^{2-}$ ion at $m / z, 598.1$ which corresponds to the neo- $\beta-1-\kappa$ DP6 oligosaccharide. The bottom spectrum (B) was obtained by isolating the $[\mathrm{M}-3 \mathrm{H}+\mathrm{Na}]^{2-}$ ion at $\mathrm{m} / \mathrm{z} 526.0$ which corresponds to the loss of the non-reducing $\alpha$-1,3-linked 3,6-anhydro-D-galactose from the neo- $\beta-1-\kappa$ DP6 oligosaccharide after treatment with $Z g G H 129$. Peaks annotated with a red star correspond to doubly charged fragments (based on the isotope pattern). Fragments annotated $(\Delta)$ correspond to water losses. Fragments indicated $(\dagger)$ correspond to sulfate losses. All unambiguous fragments are reported on the structures.

Figure 4. Activity of $\mathrm{ZgGH} 129$ on the chromogenic substrate 3,6-ADG- $p$ NP, all reactions were performed in triplicate. The pH optimum of $\mathrm{ZgGH129}$ in (A) Universal buffer [61, 62] and (B) Citrate buffer, (C) Effect of temperature on the activity of $Z g G H 129$ on 3,6-ADG- $p$ NP at pH 5.0, (D) Michaelis-

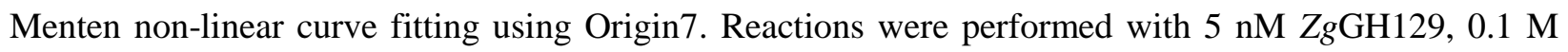
$\mathrm{NaOAc} \mathrm{pH} 5.0,0.1 \mathrm{M} \mathrm{CaCl}_{2}$ at the temperature optimum of $49^{\circ} \mathrm{C}$.

Scheme 1. Chemical synthesis of 4-nitrophenyl 3,6-anhydro- $\alpha$-D-galactopyranoside (3,6-ADG- $p$ NP).

Supplementary File 1: Expanded GH129 phylogenetic tree. Only bootstraps above 70 are shown.

Supplementary File 2: ${ }^{1} \mathrm{H}$ and ${ }^{13} \mathrm{C}$ NMR spectra of synthesised compounds. 
A

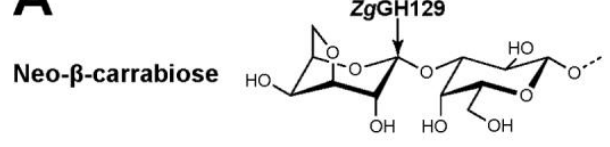

Neo-k-carrabiose

Neo-I-carrabiose
B

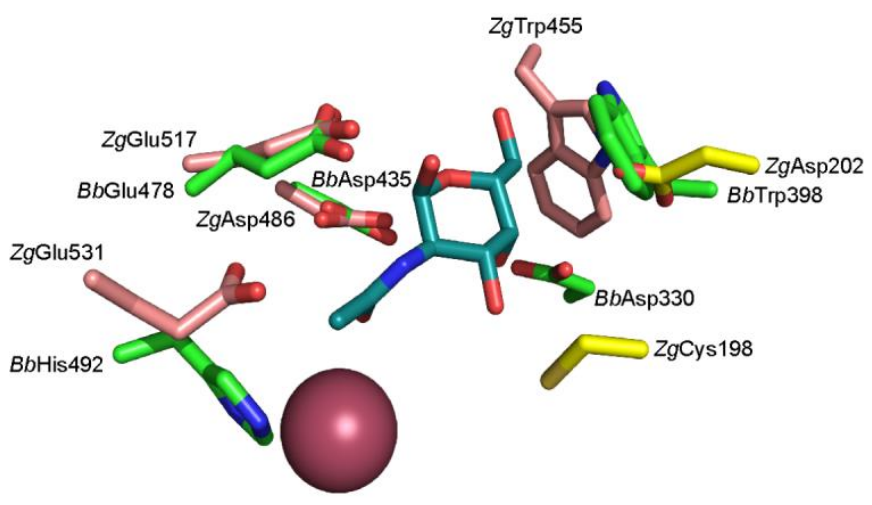

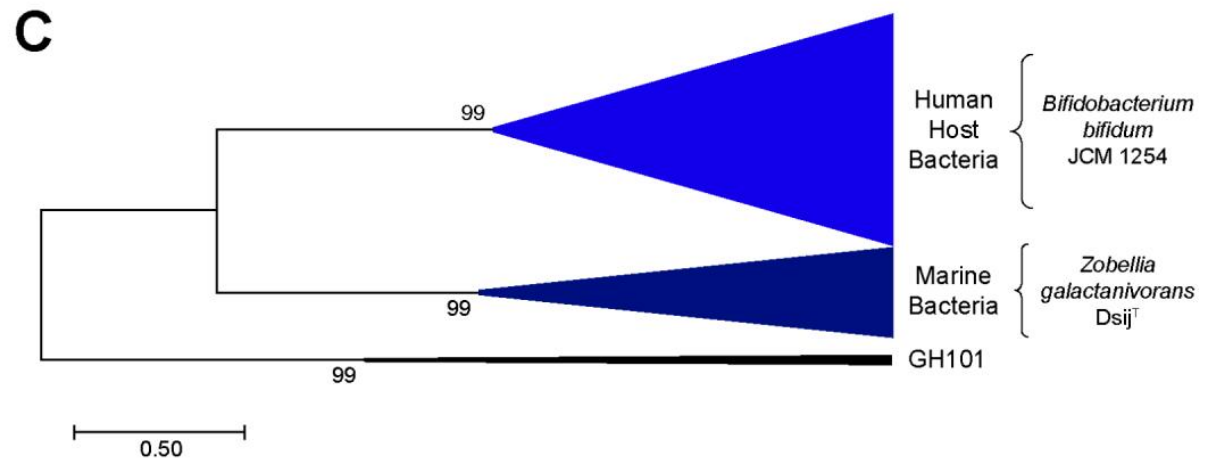

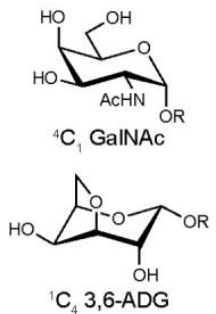

${ }^{1} C_{4}$ 3,6-ADG

\section{Figure 1.}




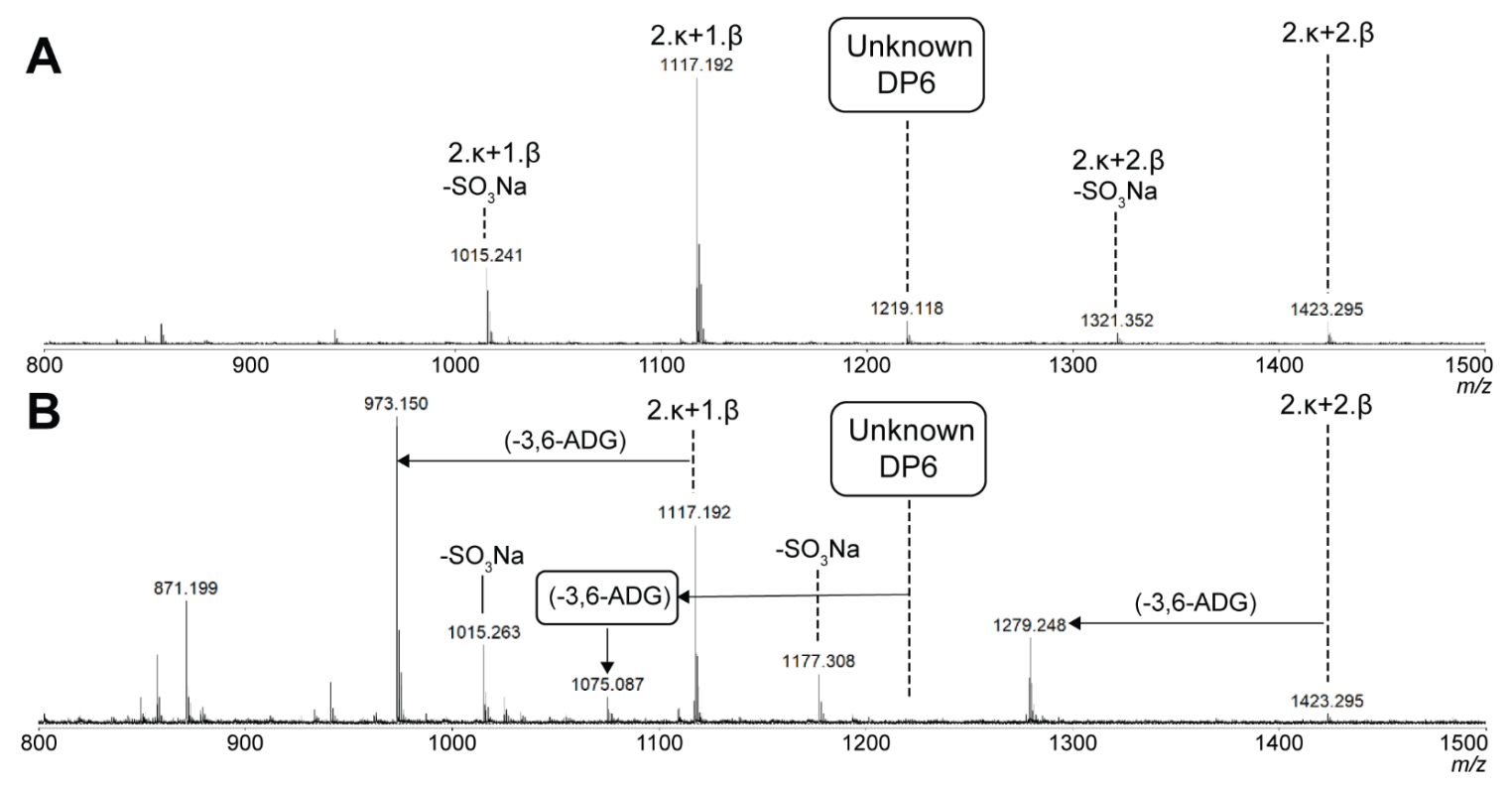

Figure 2. 


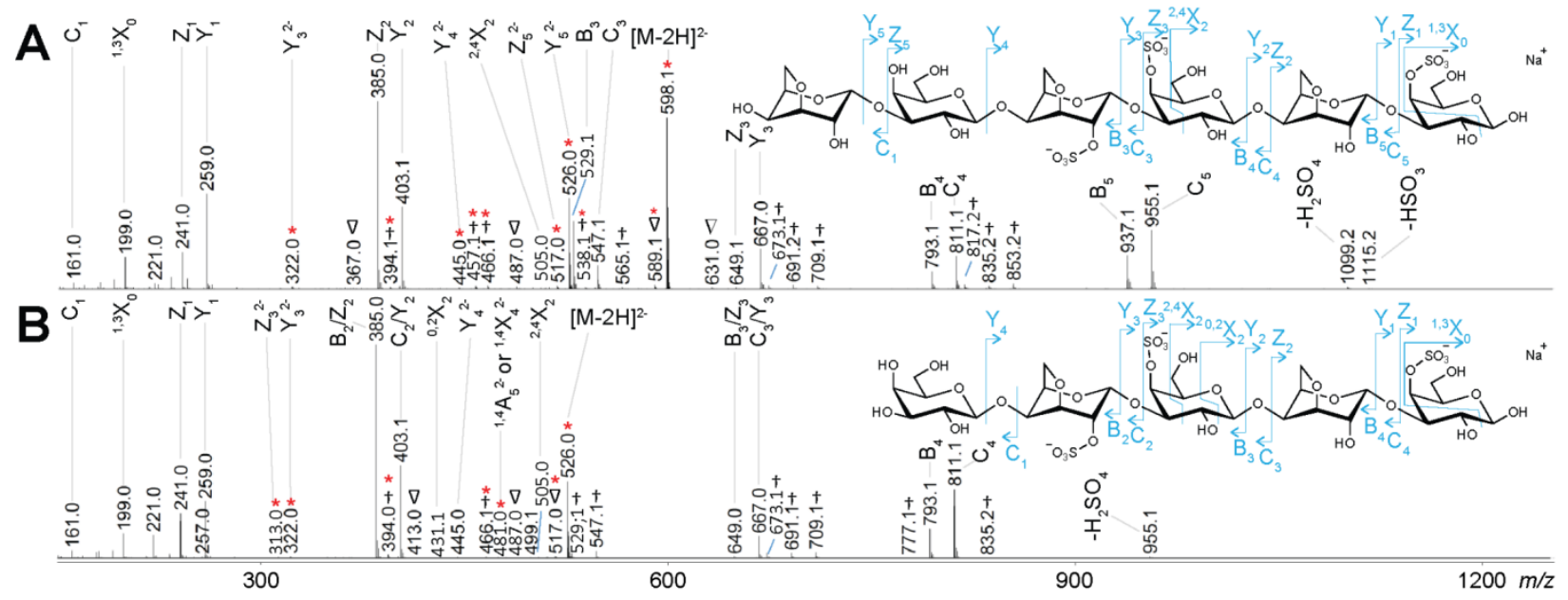

Figure 3. 
A

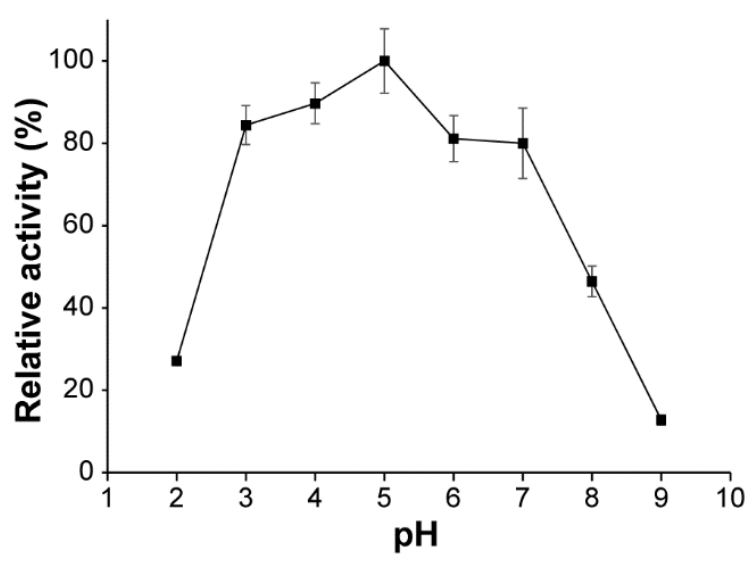

B

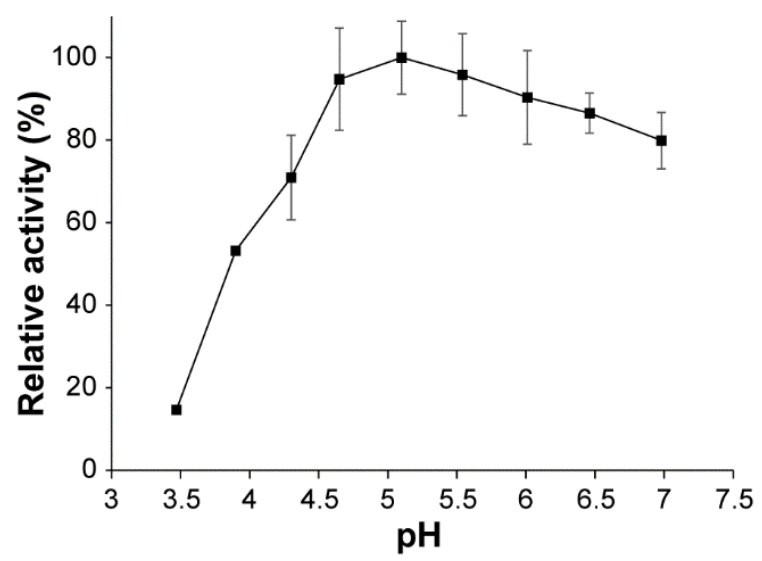

C

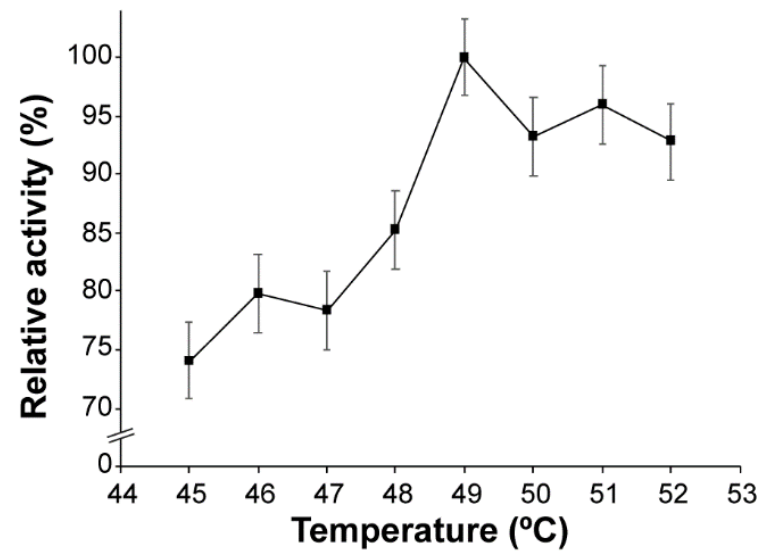

D

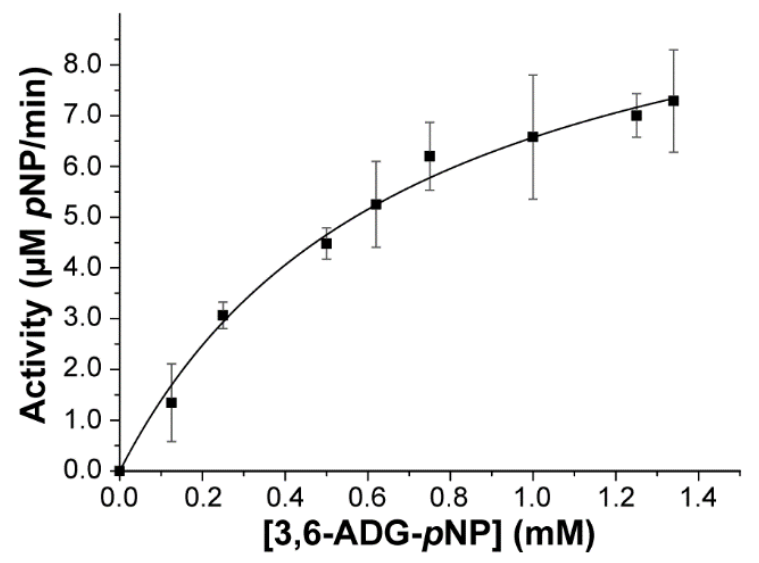

Figure 4. 


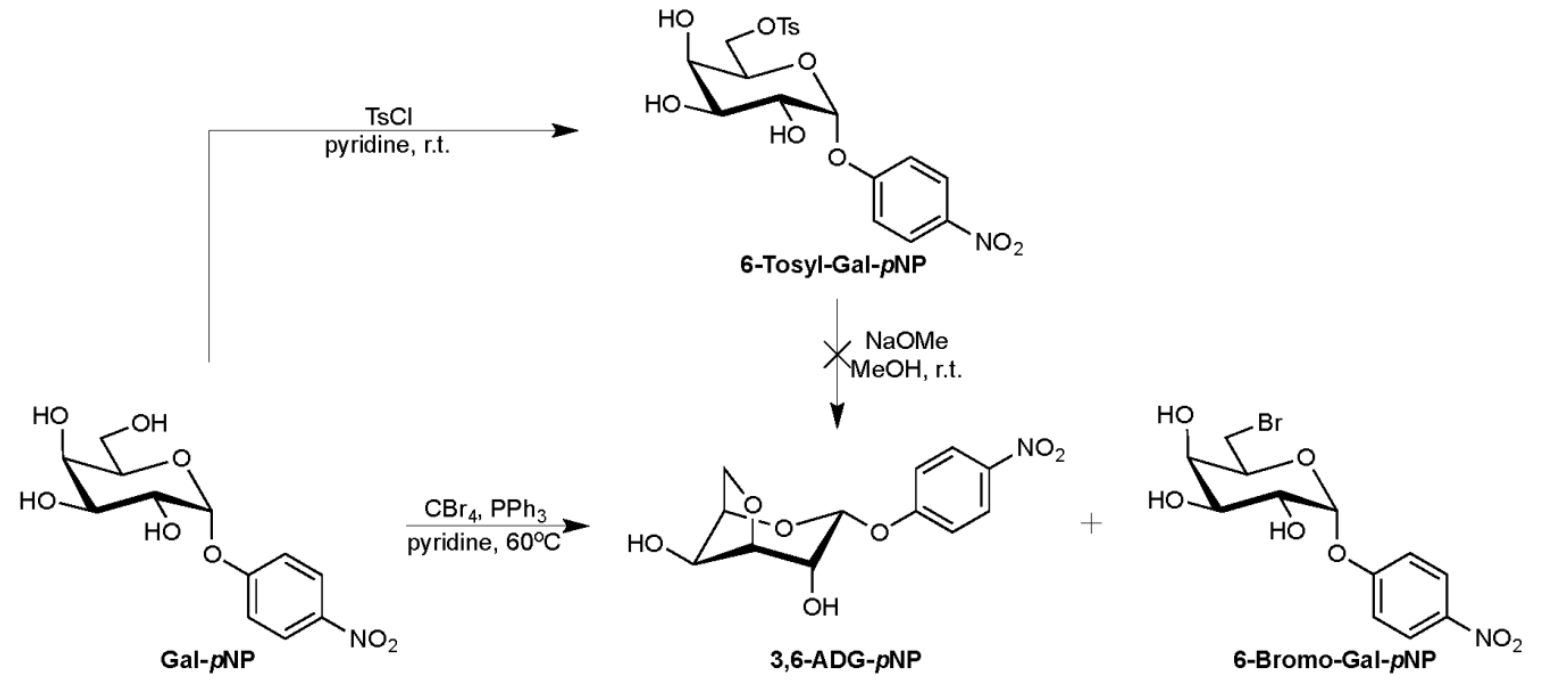

Scheme 1. 